Д.В. Погонцева

\title{
ОСОБЕННОСТИ ОТНОШЕНИЯ \\ К ДЕВУШКАМ С РАЗЛИЧНЫМ ОФОРМЛЕНИЕМ ВНЕШНЕГО ОБЛИКА: РОЛЬ ХИДЖАБА
}

\begin{abstract}
Аннотация. В работе автор рассматривает особенности формирования отношения к женщинам, в связи с этно-религиозными характеристиками оформления их внешнего облика (на примере хиджаба). Объектом исследования выступили 56 человек (30 женщин и 26 мужчин) в возрасте от 18 до 30 лет (средний возраст - 27 лет), жители г. Ростова-на-Дону. Данная возрастная группа была выбрана в связи с тем, что молодежь является наиболее подверженной влиянию и манипуляциям группой. В исследовании была использована "шкала враждебности» Кука-Медлей (методика переведена и адаптирована Ю.А. Менджерицкой), а также авторская анкета, которая состояла из стимульного материала (2 комплекта фотографий по 5 девушек, в одном случае это была портретная съёмка в анфас с натуральным макияжем и распущенными волосами, второй комплект - те же девушки, но в чёрном хиджабе), респондентам предлагалось оценить отношение к девушкам, представленным на фотографиях по шкале от дружелюбно, до враждебно. Исходя из полученных результатов мы можем говорить о том, что уровень агрессии может обуславливать негативное, враждебное отношение к девушкам-мусульманкам (основанное исключительно на оформлении внешнего облика), кроме того мужчины чаще оценивают свое отношение к девушкам в хиджабе как более враждебное. Ключевые слова: хиджаб, сочиальная психология, внешний облик, оформление внешнего облика, психология отношения, ислам, враждебность, агрессивность, дружелюбность, дискриминация.
\end{abstract}

Abstract. In this paper the author considers the peculiarities of the treatment of women in connection with the ethno-religious
characteristics of the processing of their appearance (for example hijab). The object of the study were 56 people (30 women
and 26 men) aged 18 to 30 years (mean age 27 years), residents of the city of Rostov-on-Don. This age group was chosen due
to the fact that young people are most susceptible to influence and manipulation group. The study used Cook-Medley hostility
scale (method translated and adapted Yu.A.Mendzheritskoy), as well as the author's questionnaire, which consisted of stimulus
material (2 sets of photographs - the 5 girls in first case was a portrait shot from the front with natural make-up, a second set-
the same girl, but in black hijab), respondents were asked to assess the attitude of the girls represented in the photographs
on a scale from friendly to hostile. Based on the results we can say that the level of aggression can lead to a negative, hostile
attitude towards the Muslim girl (based solely on the design of external appearance), moreover men were more likely rated
their attitude to the girls in hijab as a more hostile. Key words: aggressiveness, hostility, Islam, psychology of attitude, design of external appearance, appearance, social psychology, hijab, friendliness, discrimination.

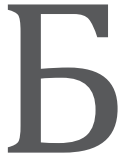
ольшинство стран в современном мире представляют собой поликультурное пространство, в котором проживают и взаимодействуют представители разных этнических групп, народов с различными религиозными убеждениями. В то же время события последних лет стали причиной возникновения устойчивого словосочетания «исламский фактор». Начиная с терактов в США (11 сентября 2001 г.), Москве, Ставропольском крае, в различных регионах Северного Кавказа, ситуация с Исламским государством и терактом во Франции (7 января 2015 г.) в

Исследование выполнено при финансовой поддержке ЮФУ (грант «Угрозы национальной безопасности в условиях геополитической конкуренции и модели агрессивного и враждебного поведения молодежи», тема № 213.01-07-2014/15ПЧВГ (проектная часть внутреннего гранта ЮФУ)). 
редакции газеты «Шарли Эбдо» (Charlie Hebdo) и заканчивая интеграцией ислама в традиционно «не мусульманские» страны (США, Канада, большинство Европейских стран, Россия и т.д.), данная тема (взаимоотношение с исламским миром) неоднократно возникает в различных работах по политологии, конфликтологии, социологии, философии, психологии $[1,2,3,4]$. Говоря о специфике Юга России, Э.Ф. Шарафутдинова [5] отмечает, что в последнее время фиксируется рост исламского интегризма в ряде республик Северного Кавказа. Автор также отмечает, что нередко ислам принимает форму религиозного радикализма, а это в свою очередь, способствует возникновению таких явлений, как терроризм, экстремизм, шахидизм (террор смертников-самоубийц) и т.д. И спецификой современного терроризма Э.Ф. Шарафутдинова называет появление женщин-террористок, «шахидок», феномен, который вошёл в жизнь России после захвата заложников в театре на Дубровке в Москве, в котором принимали участие и женщины-террористки. В такой ситуации категоризация Другого по внешнему облику выходит на первый план. И как отмечает В.А. Лабунская, «внешний облик - становится одним из важнейших средств построения типологий, выделения и распознания определенных социальных групп, страт, описания стилей жизни. ... Внешний облик человека становится способом визуальной коммуникации и стратификации» [6]. Но не только внешний облик человека, цвет кожи, волос и глаз, стиль одежды может служить маркером религиозной принадлежности, пола, географического происхождения, этнического происхождения, профессии и социального статуса. И хотя в Татарстане хиджаб является нормой одежды, актуальность проблемы хиджаба в России стала активно наростать после конфликта в Ставрополье в 2012-2013 гг., когда девочки из мусульманской диаспоры начали посещать школу в платке. Итогом данного конфликта можно считать тот факт, что летом 2013 г. Верховный суд России, вслед за Ставропольским краевым судом, разрешил правительствам субъектов Российской Федерации накладывать запрет на ношение в школах головных уборов и т.н. "религиозной одежды".

В конституции большинства стран заложен пункт против дискриминации по религиозному признаку и свободе вероисповедания, существует Закон РСФСР от 25.10.1990 «О свободе вероисповеданий». В этом законе указывается гарантированная Конституцией РСФСР свобода вероисповеда- ний, которая включает право каждого гражданина свободно выбирать, иметь и распространять религиозные и атеистические убеждения, исповедовать любую религию или не исповедовать никакой и действовать в соответствии со своими убеждениями при условии соблюдения законов государства. А также Федеральный закон «0 свободе совести и о религиозных объединениях» от 26 сентября 1997 г. (в редакции от 01.07.2011), который регулирует правоотношения в области прав человека и гражданина на свободу совести и свободу вероисповедания, а также правовое положение религиозных объединений.

Кроме этого, каждая религия имеет определённые внешние атрибуты, так для христианства это нательный крест, ладанка, нательные медальоны-иконы с ликами святых, для иудаизма это звезда Давида, для ислама это чётки у мужчин, определённое оформление внешнего облика (запрет на бритье в некоторые периоды), а у женщин - ношение хиджаба, паранджи, чадры (хотя Коран не требует скрывать от женщин лицо, в ряде исламских стран это является нормой). Об отношении к хиджабу, парандже и никабу в Европе говорит тот факт, что в 2011 г. во Франции был принят закон о запрете закрывать лицо в публичных местах (под данную статью попадают никаб и паранджа, которые скрывают лицо). До этого, в 2004 г., был принят закон о том, что нельзя демонстрировать в школе религиозную принадлежность через религиозные символы (демонстративное ношение креста, звезды Давида, хиджаба и т.д.). И в данном случае право на «свободу вероисповедания» вступает в конфликт с таким запретом, которое французское правительство обосновывает тем фактом, что Франция - светская страна (как и Россия, и большинство стран Европы). Рассматривая взаимодействие Европы с исламом, А.С. Тимощук приводит в пример реакцию жителей Кёльна на антиисламские выступления правых партий в 2008 и 2009 гг. когда участников конгресса встретили лозунгом «Если Вы не за ислам, значит, Вы за Гитлера» [7].

На фоне интереса к феномену хиджаба можно отметить ресурс http://worldhijabday.com/, основная позиция которого: «прежде чем осуждать - одень на 1 день хиджаб», всемирным днем ношения хиджаба было предложено 1 февраля. Данный ресурс включает отзывы и истории более 19 тысяч женщин со всего мира об ощущениях, чувствах и переживаниях, связанных с ношением хиджаба. Важно отметить, что на данный момент 


\section{Этнос и этничность}

зарегистрированы представители 140 стран, среди которых есть и Россия, а по заявлениям авторов проекта за 3 года существования проекта, к 1 февраля 2015 г. в проекте приняло участие около 10 миллионов женщин, как исповедующих, так и не исповедующих ислам. Также, говоря о культуре ношения хиджаба, в ряде стран, где ислам является основное религией, существуют модные показы, и как в любых культурах, мода на ту или иную цветовую палитру, орнаменты и т.д. При этом многие авторы $[4,5,7]$ подчёркивают необходимость выбора проявлять или не проявлять свою религиозную идентичность, в частности носить или не носить хиджаб, ходить или не ходить в мечеть, покупать халяльную или обычную продукцию и т.д. Поскольку в большинстве случаев социологические и психологические исследования, так или иначе, отмечают наличие исламофобии и дискриминационного отношения именно по отношению к женщине.

Большинство исследований, посвящённых предрассудкам в США, в основном сосредоточены на дискриминации темнокожих жителей Америки. В Европе большинство исследований, посвящённых предрассудкам и дискриминации, направлены на изучение иммигрантов, и в том числе - исповедующих ислам. В целом отношение к исламу во всем мире скорее негативное, подчёркивается проблема притеснения женщин в исламе, что проявляется, как в невозможности наследовать имущество после своих мужей, отсутствии возможности выйти замуж снова, в отличие от мужчин, которые имеют полное право на повторный брак, и вплоть до ношения паранджи и хиджаба. Этническая, расовая и религиозная дискриминация, как видно из ряда работ, является проблемой, которая затрагивает все сферы общественной жизни: труда, образования, СМИ; и, как правило, проявляется как на межличностном, межгрупповом уровнях, так и на уровне политических, экономических и социальных институтов. Рассматривая феномен исламофобии, Д.В. Сидоров дает следующее определение «это одна из разновидностей ксенофобии, которая выражается в страхе по отношению к исламу как явлению абсолютно непонятному и чуждому, а также всему, что с ним связано, в том числе и мусульманам; это реакция части населения на негативные проявления в исламе» [8]. Таким образом, под исламофобией понимается любая негативная оценка всего что так или иначе связано с исламом.

Другой, важный для раскрытия темы, термин - этнолукизм. Сам термин лукизм появился в
1978 г. и означает дискриминацию, основанную на внешнем облике. И как мы отмечали ранее [9] под этнолукизмом чаще понимают дискриминацию по цвету кожи, цвету волос и анатомическим особенностям строения лица, однако данный термин можно применить и к головным уборам и одежде, поскольку последние являются частным случаем оформления внешнего облика. И хотя категоризация и отнесение к религиозной принадлежности в равной степени относится и к мужчинам и женщинам, чаще поднимается вопрос о гендерной дискриминации и исламофобии, т.к. чаще в обществе поднимается вопрос о границах возможностей и ограничения для женщин. Это положение подтверждают ряд исследований, которые указывают, что в Европе до 76 \% нападок, связанных с исламофобией, направлены на женщин, исповедующих ислам, и данные нападки основаны на оформлении внешнего облика [10]. В целом, в современном обществе наблюдается повышенный интерес к социальной психологии женщин, обусловленный динамикой трансформации сложившихся гендерных отношений и связанных с ними экономических преобразований. Изменение социального положения женщин привлекает внимание к изучению «женских проблем», к исследованию «женского взгляда» на фундаментальные вопросы бытия человека. И интерес к проблемам женщин, исповедующих ислам, растёт с каждым годом, подкрепляется, в том числе, и политической ситуацией в мире.

Раскрывая суть хиджаба, О.В. Тарасенко подчёркивает, что чаще под хиджабом понимается исключительно головной платок женщины, однако данное понятие шире и включает «внешний хиджаб» (одежда, закрывающая всё тело кроме лица и кистей рук) и «внутренний хиджаб» (жизненная позиция, поведение) [11]. Внутренний хиджаб, как отмечает автор, это «жизненная позиция Хайя скромность, стеснительность, застенчивость». В свою очередь М.Г. Досанова, изучая отношение современных девушек, которые носят хиджаб, выявила, что одним из основных мотивов женщинами, проживающих в Казахстане, выбора хиджаба является «приобретение» определенного статуса и положения [12]. Для многих девушек хиджаб - это способ более выгодно выйти замуж, включение в определённые социальные группы, возможность использовать религиозность как определённый ресурс, кроме того, хиджаб является способом репрезентировать себя как «обладающую знанием о том, какой должна быть настоящая женщина». 
Таким образом, автор подчеркивает, что для большинства респондентов (женщины в возрасте от 17 до 35 лет) хиджаб является способом достижения не столько религиозных целей, сколько секулярных. М.Г. Досанова делает вывод о том, что путь в ислам для большинства девушек является путем самовоспитания, который сопровождается постоянной рефлексией относительно данного выбора и работы над собой. Таким образом, девушка сама «делает» из себя мусульманку, а в процессе данного конструирования решающую роль играет именно практика ношения хиджаба.

К таким же результатам пришла канадская исследовательница Т.Ф. Руби, проведя опрос женщин (в возрасте от 30 до 60 лет) об их опыте ношения хиджаба [13]. Респонденты, по мнению автора, чаще используют хиджаб, чтобы отгородиться от внешнего мира и, прежде всего, от взглядов посторонних мужчин. В тоже время, Т.Ф. Руби приводит в пример высказывания женщин, исповедующих ислам, но не носящих хиджаб, которые говорят о том, что в Канаде женщина в хиджабе подвергается пристальному вниманию прохожих, и поэтому говорить, что хиджаб защищает от взглядов было бы не корректно. В целом респондентки, отказавшиеся от ношения хиджаба, отмечают, что женщину в хиджабе чаще идентифицируют как «террористку», что провоцирует негативное отношение, часто сопряжённое со страхом, а в социуме таких женщин старательно избегают. Таким образом, отказываясь от хиджаба, женщины стремятся к тому, чтобы не быть объектом дискриминации, основанной на внешнем облике.

Автор также отмечает и другой интересный феномен, это оценка женщин в хиджабе как «угнетённых», некоторые жительницы Европы и Северной Америки предлагают девушкам в хиджабе снять его, предполагая, что такие женщины боятся мужа или родителей и осуждения с их стороны. Ряд акций, которые организуют в разных странах, призывают остановить «гнёт и притеснение женщин мусульманок» и чаще подразумевается, что притеснение идет от семьи и мужа, а доказательством является ношение хиджаба, паранджи и т.д. Однако такая «феминизация ислама» не находит должной поддержки со стороны женщин, исповедующих ислам. Исследование Р. МакДермотт-Леви [14] посвящалось проблемам девушек, исповедующих ислам, в сфере обучения. Так респондентки описывали, что в ситуации первого контакта с преподавателями и однокурсниками испытывали затруднения, т.к. наличие хиджаба создавало устойчивое впечатление, что его обладательница не знает английского языка, собеседники начинали говорить громче, чётко произнося каждое слово и сопровождая речь обильным количеством жестов. В целом студентки, исповедующие ислам, отмечают невежество однокурсников и преподавателей, которые знают об исламе только ту информацию, которую они получают из СМИ. Однако опыт общения привёл к тому, что отношение поменялось, и как отмечают респонденты, изменило модальность на положительную.

В зарубежных работах также часто поднимается вопрос о категоризации «другого» и о роли внешности как пускового механизма этнической дискриминации, а также роли хиджаба, особенно часто феномен женской исламской идентичности изучается в рамках иммигрантских сообществ (в том числе практика ношения паранджи, никаба, хиджаба и т.д.). Так в работе Н. Хассим [15], рассматривая вопросы глобализации ислама, затрагивает проблему изменения стереотипов в отношении женщин, исповедующих ислам, и отношение к ношению хиджаба. Рассматривая данный аспект на примере Малазии, автор отмечает, что высокий процент жителей, исповедующих ислам, «обновили» восприятие хиджаба в Малайзии, и женщины мусульманки чувствуют себя значительно более раскрепощёнными и могут демонстрировать исламскую идентичность через внешние атрибуты. Одним из основных факторов, влияющих на данный аспект, оказывают средства массовой коммуникации. Рассматривая отношение студентов, исповедующих ислам, к информации в СМИ, Л. Браун с соавторами указывают, что студенты разделяют мнение о том, что британские СМИ дать искажённое представление об исламе и мусульманских странах [16]. Последние представлены в виде экономически отсталых и религиозно-консервативных стран, особенно в сравнении с рядом западных стран, в том числе СМИ проводят параллель между положением женщин в западном обществе и в исламе. Между тем, по словам участников этого исследования, такие искажения привели к тому, что к мусульманам относятся с подозрением, а иногда случайная встреча сопровождается физическими и словесными оскорблениями. Кроме того, такого рода искажения информации также негативно влияют на коллективную самооценку и культурную самобытность молодёжи, исповедующей ислам. 


\section{Этнос и этничность}

В другой работе У. Махмуд и В. Свами [17] подчёркивают важность оформления внешнего облика для категоризации другого человека, как исповедующего ислам. В своем исследовании авторы предложили мужчинам (исповедующим и не исповедующим ислам) оценить внешнюю привлекательность и ум девушек в хиджабах и без них. В своей работе авторы отмечают, что визуальные маркеры религиозной принадлежности могут привести к более негативному восприятию, как внешней привлекательности, так и ума - независимо от вероисповедания субъекта оценки (мужчин-респондентов). Однако, интересен тот факт, что мужчины, не исповедующие ислам, в целом оценили умственные способности девушек значимо выше. Таким образом, данное исследование также указывает на стереотип будто женщины, исповедующие ислам, менее образованные из-за своего положения в целом.

Однако, как показывают некоторые исследования, в странах, где количество иммигрантов невысоко, дискриминация проявляется на уровне «свой/чужой», начиная с детского сада [18]. Следует отметить, что проблема иммиграции и категоризации иммигрантов по внешнему облику является актуальным вопросом практически для всех Европейских стран. Она также применима к российской действительности и отражается в категоризации «таджики» - всех иммигрантов из Средней Азии, а также категоризации всех народов Кавказа как «лиц кавказской национальности», и приписывание им (жителям Кавказа) ислама, как основной религии, несмотря на то, что ряд регионов исповедуют христианство (Абхазия, Грузия, Армения и т.д.).

В Российской конституции в 19-ой статье указывается, что государство гарантирует равенство прав и свобод человека и гражданина независимо от пола, расы, национальности, языка, происхождения, имущественного и должностного положения, места жительства, отношения к религии, убеждений, принадлежности к общественным объединениям, а также других обстоятельств [19]. Таким образом, законодательно запрещаются любые формы ограничения прав граждан по признакам социальной, расовой, национальной, языковой или религиозной принадлежности, в то же время, используя различные стереотипные суждения мы делим людей на группы по внешнему облику, а каждую из этих групп наделяем определёнными характеристиками, которые могут, как соответ- ствовать данной группе, так и быть ложными. Важно отметить, что этнические стереотипы как отражение социально-культурных особенностей этноса и исторически формирующихся межэтнических отношений, являются ярким воплощением общественного мнения на определенном историческом этапе [20]. Этнические стереотипы обладают относительной устойчивостью, скрупулезно отражают мнение этноса о себе (автостереотипы) и упрощённо о другом этносе (гетеростреотипы), обязательно имеют знаковую направленность. Связь этнических стереотипов с действительностью зависит от знаний, уровня и состояния межнациональных отношений, а также от формы существующего соседства. Хотя в некоторых работах затрагивается проблемы баланса между позицией мультикультурализма и ограничений на иммиграцию людей из «чужих» культур. Так К. Хо рассматривает проблему соседства разных народов и проблемы иммиграции на примере Австралии [21]. Необходимо отметить, что Австралия долгое время проводила политику мультикультуризма и лояльно относилась к процессам миграции и, прежде всего, иммиграции, однако теперь власти Австралии обеспокоены тем, что коренное население Австралии резко сокращается, и параллельно с этим растет количество исповедующих ислам, в том числе, рождённых уже в Австралии. Это провоцирует анти-исламские заявления, которые чаще всего сводятся к дискриминации женщин как исповедующих ислам (в пример приводятся хиджаб и парандажа), так и притеснение женщин, не исповедующих ислам (примером является статистика преступлений против женщин, от домогательств до изнасилования, за которые были осуждены лица, исповедующие ислам).

Таким образом, соседство различных народов не всегда приводит к познанию и принятию тех или иных религиозных или этнических групп. Кроме того, как отмечает К. Хо, консервативные члены правительства Австралии (и что интересно, многие женщины-политики) инициировали общественные дискуссии о правах мусульманских женщин и девочек носить платок или хиджаб, о правомерности применения законов шариата в Австралии, а также вмешательство мусульманской диаспоры в дебаты об абортах. В основе всех этих дебатов является обеспокоенность по поводу мусульманских австралийцев и их отказа ассимилироваться с основной австралийской культурой, которые всё чаще сводятся именно к оформлению 
внешнего облика женщин. Всё чаще в австралийских СМИ звучит позиция, что женщины, носящие хиджаб и парандажу, являются «рабами жестоких религиозных кодов». Автор также приводит в пример высказывания сенатора из Америки (Бренда Уолкер), которая выступает против иммиграции мусульман, аргументируя тем, что это равносильно «импорту женоненавистничества».

В тоже время, необходимо понимать, что принадлежность к исламскому сообществу на практике не означает применения определённой поведенческой практики и исключения иных стратегий поведения и норм. В целом, К. Хо, на примере взаимоотношений женщин с исламом (как внутри, так и вне религии), демонстрирует роль женщин в любых межнациональных конфликтах, поскольку также существует обратная указанной, исламская риторика, которая указывает на грубое отношение к женщинам, исповедующим ислам, таким образом существуют взаимные обвинения, основанные на религии, и к ним добавляются высказывании о гендерной дискриминации внутри мусульманской диаспоры, так Дж. Буш (старший) в 2002 г. выступил перед беженцами из Афганистана, указав, что раньше «в Афганистане матери и дочери были пленники в собственных домах».

Однако, рассматривая историю Юга России, важно отметить, что соседство с республиками Северного Кавказа, а также торговые и другие экономические и политические связи обеспечивали взаимодействие между людьми, как разных национальностей, так и разного вероисповедания, и, как мы уже отмечали ранее [22, 23], отношение к исламу скорее негативно враждебное, чем позитивнонейтральное. С другой стороны, распространение ислама и увеличение числа межконфессионаьных браков приводит к тому, что девушки со славянским внешним обликом, воспитанные в христианской религии, выходят замуж за представителей ислама, принимают религию мужа, и одевают хиджаб, паранджу и т.д.

Динамика современного мира диктует необходимость презентировать «себя для другого» максимально выразительно и понятно. В то же время существует фактор субъективности как при создании образа, так и при его восприятии и анализе Другим. В настоящее время понимание внешнего облика как конструкта «я-для-другого» развивается в работах В.А. Лабунской [24]. Автор рассматривает «внешнее Я личности» как совокупность устойчивых (физиогномика, индивидуально-кон- ституциональные характеристики внешности), среднеустойчивые (оформление внешности: прическа, косметика и одежда) и динамических параметров выражения (экспрессивное, невербальное поведение), организующихся в пространственновременные структуры и перестраивающиеся по ходу развития психофизиологических, психологических и социально-психологических компонентов структуры личности.

В связи с тем, что существует повышенный интерес к проблеме ислама и отношение к лицам, исповедующим ислам, но нет достаточного количества работ, посвященных особенностям формирования отношения к представителям ислама, и особенностям оценки Другого, основываясь на оформлении внешнего облика, нами была поставлена цель: изучить особенности формирования отношения к женщинам, в связи с этно-религиозными особенностями оформления их внешнего облика (на примере хиджаба).

Для этого нами были разработаны и подготовлены 2 комплекта фотографий, на которых были изображены 5 девушек, в одном случае это была портретная съёмка анфас с натуральным макияжем и распущенными волосами (две блондинки, две брюнетки и одна шатенка), второй комплект те же девушки, но в черном хиджабе. Чтобы сгладить различия в оттенках кожи, цвете волос и глаз, мы также перевели все фотографии в черно-белый диапазон. Респондентам предлагалось оценить своё отношение к девушкам, представленным на фотографиях, по шкале от дружелюбно, до враждебно. Также респондентам предлагалось заполнить «шкалу враждебности» Кука-Медлей (методика переведена и адаптирована Ю.А. Менджерицкой) [25], разработанную для измерения интенсивности отношений враждебности, агрессивности и подозрительности. Методика содержит 27 утверждений. Испытуемым необходимо выразить своё отношение к этим утверждениям, пользуясь шкалой, имеющей 6 градаций: «всегда», «часто», «иногда», «случайно», «редко», «никогда».

В пилотажном исследовании, в качестве респондентов выступили 56 человек (30 женщин и 26 мужчин) в возрасте от 18 до 30 лет (средний возраст 27 лет), жители г. Ростова-на-Дону. Молодежь - это социально-демографическая группа, выделяемая на основе совокупности возрастных характеристик, особенностей социального положения и определённых социально-психологических качеств, различные авторы выделяют возрастные 


\section{Этнос и Этничность}

границы по-разному, однако можно говорить о том, что в целом это период между детством и взрослостью, и в нашем исследовании мы взяли широкие рамки от 18 до 30 лет. Таким образом, нынешнее положение в России и в мире диктует повышенный интерес к изучению молодежи, как наиболее подверженной влиянию и манипуляциям группу. Надежность полученных данных обеспечивается использованием следующих методов математической статистики: Z-критерий Уилкоксона для определения статистически значимого сдвига, коэффициент корреляции Спирмена для выявления связи между переменными; U-критерий Манна-Уитни для выявления различий между выборками.

На первом этапе мы сравнили результаты ответов мужчин и женщин, для этого мы использовали тест Манна-Уитни. Нами были выявлены ряд значимых различий, так показатель «цинизм» выше у женщин $(Z=-2,11$, при $\mathrm{p}<0,05)$, в то время как показатель «агрессивность» значимо выше у мужчин $(Z=2,19$, при $\mathrm{p}<0,05)$, в тоже время по шкале враждебности значимых различий не было обнаружено, и в среднем показатель по выборке ниже среднего.

При оценке фотографий также были обнаружены значимые различия, необходимо отметить, что отношение к девушкам, представленным на фото, кодировались от 1 - дружелюбно, до 9 - враждебно, таким образом, чем выше средний балл, тем более негативное отношение отмечали респонденты. Интересно отметить, что по средним баллам можно говорить о том, что отношение к девушкам без хиджаба более дружелюбное (Мф1 = 3,1; Мф2 = 2,2; Мф3 = 2,3; Мф4 = 2,5; Мф5 = 3,7), отношение к девушкам в хиджабе отношение скорее негативное (Мф6 = 5,8; Мф7 = 5,15; М $\phi 8=5,32 ; \quad$ М $\phi 10=5,8)$, кроме портрета $9(\mathrm{M} \phi=3,9)$ который чаще оценивают более дружелюбно. На этом портрете изображена девушка с типичным славянским внешним обликом (округлое лицо, светлые волосы, большие голубые глаза), так же при заполнении несколько респондентов спросили «почему среди девушекмусульманок - портрет монахини», таким образом, чёрный платок на голове ряд респондентов расценили как «не хиджаб», именно благодаря внешнему облику девушки. В целом, девушки оценивали портреты более дружелюбно, так были получены значимые различия по оценке девушки на фотографии $3(\mathrm{Z}=2,01$; при $\mathrm{p}<0,05$; девушка без хиджаба), фотографии $4(\mathrm{Z}=4,06$; при $\mathrm{p}<0,05$; девушка без хиджаба), фотографии $6(\mathrm{Z}=3,17$; при $\mathrm{p}<0,05$; девушка в хиджабе), фотографии $8 \quad(\mathrm{Z}=2,41$; при $\mathrm{p}<0,05$; девушка в хиджабе), фотографии 6 $(\mathrm{Z}=3,44$; при $\mathrm{p}<0,05$; девушка в хиджабе).

Результаты корреляционного анализа, в свою очередь, указывают на то, что уровень цинизма не влияет на модальность отношения к другому человеку. В тоже время уровень агрессивности имеет прямую корреляционную связь с выраженностью негативного отношения, так нами была обнаружена связь показателя агрессивности с оценкой фотографий 5 (девушка без хиджаба) (r=0,27; при $\mathrm{p}<0,05)$, а также фотографий $6(\mathrm{r}=0,46$; при $\mathrm{p}<0,05), 7(\mathrm{r}=0,28$; при $\mathrm{p}<0,05), 8(\mathrm{r}=0,54$; при $\mathrm{p}<0,05), 9$ ( $\mathrm{r}=0,29$; при $\mathrm{p}<0,05), 10$ ( $\mathrm{r}=0,40$; при $\mathrm{p}<0,05)$ - на которых изображены девушки в хиджабе. В целом девушку на фотографии 5 (девушка без хиджаба) большинство респондентов описали как «хитрая, напряжённая и неприятная», что можно объяснить напряжённым взглядом (прищуренные глаза, плотно сжатые губы и т.д.). Так как большинство определений «дискриминации» сводится к проявлению враждебности и агрессивности, то полученные данные могут косвенно указывать на тенденцию к проявлению дискриминации по отношению к девушкам в хиджабах. Однако, для подтверждения данной взаимосвязи, в дальнейшем мы планируем использовать методику «Принятие дискриминационного отношения», предложенную В.А. Лабунской и А.А. Бзезян [26].

Мы также использовали Z-критерий Уилкоксона для того, чтобы выявить существуют ли значимые различия в оценке одних и тех же девушек в хиджабах и без него. Нами были обнаружены значимые различия во всех пяти случаях (Ф1Ф6 $\mathrm{Z}=5,33$; при $\mathrm{p}<0,05 ;$ Ф2Ф7 $\mathrm{Z}=5,57$; при $\mathrm{p}<0,05$; ФЗФ8 Z=5,57; при $\mathrm{p}<0,05 ;$ Ф Ф9 $\mathrm{Z}=3,68$; при $\mathrm{p}<0,05 ;$ Ф5Ф10 Z = 3,67; при p < 0,05). Полученные нами данные на прямую указывают на то, что существует влияние оформление внешнего облика на формирование отношения. Несмотря на то, что существует определённый диапазон отношения к девушкам как в хиджабе, так и без него, к девушке в хиджабе отношение хуже, чем к той же девушке с распущенными волосами.

Исходя из полученных результатов, мы можем сделать вывод о том, что уровень агрессии может обуславливать негативное, враждебное отношение к девушкам-мусульманкам (основанное исключительно на оформлении внешнего облика), кроме того мужчины чаще оценивают свое отношение к девушкам в хиджабе как более враждебное. Одна- 


\section{Психология и психотехника 3(78) • 2015}

ко полученные нами результаты также указывают на то, что на отношение могут влиять как личные стереотипы (что доказывают оценки девушек без хиджаба, ближе к срединным показателям, и отдельные негативные оценки), так и трудности при категоризации (например, оценка фотографии 9, когда хиджаб оценили как одеяние монахини).

В целом, несмотря на то, что Южный федеральный округ - поликультурный, а близость с исламскими народами Кавказа формирует определенное нейтральное отношение к представителям различных религий, девушек со славянским внешним обликом одетых в традиционный для ислама головной убор - воспринимают значимо враждебнее, чем этих же девушек с непокрытой головой. Рассматривая данную проблему шире, мы можем отметить, что в данном случае срабатывает определенное наслоение оценок, с одной стороны - оценка привлекательности девушки и приписывание девушкам определенных характеристик [27], а с другой стороны - категоризация и дискриминация девушек с определенным оформлением внешнего облика [28]. Однако, рассматривая проблему исламофобии в России и сравнивая с отношением к исламу в странах Европы, Северной Америки и Австралии, можно предположить, что фактор сближения культур оказывает позитивный эффект. Опыт общения, например с мусульманами из Татарстана, формирует более позитивную установку ко всем представителям ислама, что также может объяснить полученные результаты.

Таким образом, целью нашей дальнейшей работы мы видим увеличение выборки и проверку гипотезы о взаимосвязи уровня враждебности и агрессивности на формирование отношения к девушкам с «европейским» и с «мусульманским» оформлением внешнего облика. В дальнейшем, кроме фотографий с распущенными волосами и в хиджабе, мы планируем добавить фотографии девушек в цветных платках (косынка, завязанная под подбородком на «русский» манер) и девушек в типичных головных уборах христианских (католических) монахинь, т.к. данные платки и головные уборы схожи по своему характеру - открыто лицо, закрыты волосы и шея, но несут различные стереотипы. А также выявить отношение к исламу в целом и роль отношения к исламу при формировании отношения к девушкам в хиджабе. Мы также считаем необходимым разработать анкету-фильтр для определения религиозных убеждений респондентов, поскольку в пилотажном исследовании приняли участие молодые люди как верующие (православные), так и придерживающиеся атеистических убеждений, но не было респондентов, исповедующих ислам. В то же время ряд работ [9; 16] указывают на то, что такие различия могут быть обнаружены.

\section{Список литературы:}

1. Лабунская В.А., Бзезян А.А. Особенности оценивания различных компонентов этнокультурных типов внешнего облика как проявление дискриминационного отношения // Российский психологический журнал. 2013. Т. 10 . № 3. С. 37-43.

2. Муращенкова Н.В. Патриотизм как фактор профилактики молодежного экстремизма: социально-психологический подход // Психология и психотехника. 2014. № 9. С. 104-107. (DOI: 10.7256/2070-8955.2014.9.12635).

3. Ракитянский Н.М.. Рассмотрение исламского менталитета (политико-психологическое эссе) // Международные отношения. 2014. № 2. C. 104-107. (DOI: 10.7256/2305-560X.2014.2.11478).

4. Федорова Ю.Е. Ислам в восприятии современного европейского сообщества: стереотипы и реальность // Философская мысль. 2014. № 7. С. 99-125. (DOI: 10.7256/2409-8728.2014.7.13036. URL: http://e-notabene.ru/fr/article_13036. html).

5. Шарафутдинова Э. Женский терроризм в контексте исламского интегризма // Государственное и муниципальное управление. Учёные записки СКАГС. 2011. № 4. С. 170-180.

6. Лабунская В.А. «Видимый человек» как социально-психологический феномен // Социальная психология и общество. 2010. № 1. С. 26-39.

7. Тимощук А.С. Образование и право как инструменты государственной политики в области этноконфессиональной безопасности // Вестник Владимирского юридического института. 2014. № 2(31). С. 61-64.

8. Сидоров Д.В. Исламофобия современной России // Научно-аналитический журнал Обозреватель-0bserver. 2014. № 5(292). С. 34-41.

9. Погонцева Д.В. Этно-лукизм: взгляд на проблему // Национальная безопасность / nota bene. 2013. № 6. C. 144-150. (DOI: 10.7256/2073-8560.2013.6.9490).

10. Hopkins C.T. Social reproduction in France: Religious dress laws and laïcité // Women's Studies International Forum, Vol. 48, January-February 2015, p. 154-164.

11. Тарасенко О.В. Хиджаб в исламской религии // Вестник Московского государственного лингвистического университета. 2010. № 581. С. 217-226. 


\section{Этнос и Этничность}

12. Досанова М.Г. Городские женщины в хиджабе. Новый феномен в Казахстане? // Вестник РУдН. Серия «Социология». 2010. № 3. С. 5-11.

13. Ruby T.F. Listening to the voices of hijab // Women's Studies International Forum, Vol. 29, Iss. 1, January-February 2006, p. 54-66.

14. McDermott-Levy R. Going alone: The lived experience of female Arab-Muslim nursing students living and studying in the United States // Nursing Outlook, Volume 59, Issue 5, September-October 2011, Pages 266-277.e2.

15. Hassim N. Hijab and the Malay-Muslim Woman in Media // Procedia-Social and Behavioral Sciences, Vol. 155, 6 November 2014, p. 428-433.

16. Brown L., Brown J., Richards B. Media representations of Islam and international Muslim student well-being // International Journal of Educational Research, Vol. 69, 2015, p. 50-58.

17. Mahmud Y., Swami V. The influence of the hijab (Islamic head-cover) on perceptions of women's attractiveness and intelligence // Body Image, Vol. 7, Issue 1, January 2010, p. 90-93.

18. Wagner J.T. Do anti-immigrant sentiments track into Danish classrooms? Ethnicity, ethnicity salience, and bias in children's peer preferences / J.T. Wagner, L.B. Camparo, V. Tsenkova, J.C. Camparo // Intern. J. of Educ. Research. 2008. Vol. 47, is. 5. P. 312-322.

19. Арсельгов А.У. Этнические стереотипы в культуре: на примере культур Северного Кавказа: Дис. ... канд. филос. н. Ростов-на-Дону, 2011. 147 с.

20. Ho C. Muslim women's new defenders: Women's rights, nationalism and Islamophobia in contemporary Australia // Women's Studies International Forum, Vol. 30, Iss. 4, July-August 2007, p. 290-298.

21. Погонцева Д.В., Наседкина Ю.В. Отношение молодежи к разным конфессиям в зависимости от их религиозной идентичности // Научно-методический электронный журнал «Концепт». 2014. Т. 20. С. 4806-4810.

22. Погонцева Д.В., Наседкина Ю.В. Отношение молодежи к представителям различных религиозных конфессий // Education Sciences and Psychology. 2013. № 2(24). С. 49-53.

23. Лабунская В.А. Интерпретация невербального поведения в межличностном общении: Автореф. дис. ... докт. психол. H. М., 1989.

24. Лабунская В.А., Менджерицкая Ю.А., Бреус Е.Д. Психология затрудненного общения: Теория. Методы. Диагностика. Коррекция: Учебн. пос. для студ. высших учебных заведений. М., 2001.

25. Лабунская В.А., Бзезян А.А. Методология исследования дискриминационного отношения к представителям этнокультурных групп в различных ситуациях взаимодействия // Теоретические проблемы этнической и кросскультурной психологии: Материалы четвертой международной научной конференции, 30-31 мая 2014 г. / Отв. ред. В.В. Гриценко. Смоленск: Смоленский гуманитарный университет, 2014. Т. 1. С. 50-55.

26. Погонцева Д.В. Представления современной молодежи о внешней красоте женщины // Российский психологический журнал. 2008. Т. 5. № 4. С. 110-112.

27. Погонцева Д.В. К вопросу о дискриминация по внешнему облику // Северо-Кавказский психологический вестник. 2011. T. 9. № 2. С. 47-50.

28. Бзезян А.А. Особенности этнической идентичности как предиктор принятия дискриминационного отношения к этнокультурным группам // Национальная безопасность / nota bene. 2014. № 3. C. 454-464. (DOI: 10.7256/20738560.2014.3.12083).

29. Погонцева Д.В. Виды дискриминации по внешнему облику // Психология и психотехника. 2013. № 9. С. 858-861. (DOI: 10.7256/2070-8955.2013.9.9106).

30. Бзезян А.А. Влияние гендера этнокультурного типа внешнего облика на степень позитивности оценки // Психология и психотехника. 2014. № 1. C. 83-90. (DOI: 10.7256/2070-8955.2014.1.9704).

\section{References (transliteration):}

1. Labunskaya V.A., Bzezyan A.A. Osobennosti otsenivaniya razlichnykh komponentov etnokul'turnykh tipov vneshnego oblika kak proyavlenie diskriminatsionnogo otnosheniya // Rossiiskii psikhologicheskii zhurnal. 2013. T. 10. № 3. S. 37-43.

2. Murashchenkova N.V. Patriotizm kak faktor profilaktiki molodezhnogo ekstremizma: sotsial'no-psikhologicheskii podkhod // Psikhologiya i psikhotekhnika. 2014. № 9. S. 104-107. (DOI: 10.7256/2070-8955.2014.9.12635).

3. Rakityanskii N.M. Rassmotrenie islamskogo mentaliteta (politiko-psikhologicheskoe esse) // Mezhdunarodnye otnosheniya. 2014. № 2. S. 104-107. (DOI: 10.7256/2305-560X.2014.2.11478).

4. Fedorova Yu.E. Islam v vospriyatii sovremennogo evropeiskogo soobshchestva: stereotipy i real'nost' // Filosofskaya mysl'. 2014. № 7. S. 99-125. (DOI: 10.7256/2409-8728.2014.7.13036. URL: http://e-notabene.ru/fr/article_13036.html).

5. Sharafutdinova E. Zhenskii terrorizm v kontekste islamskogo integrizma // Gosudarstvennoe i munitsipal'noe upravlenie. Uchenye zapiski SKAGS. 2011. № 4. S. 170-180.

6. Labunskaya V.A. «Vidimyi chelovek» kak sotsial'no-psikhologicheskii fenomen // Sotsial'naya psikhologiya i obshchestvo. 2010. № 1. S. 26-39.

7. Timoshchuk A.S. Obrazovanie i pravo kak instrumenty gosudarstvennoi politiki v oblasti etnokonfessional'noi bezopasnosti // Vestnik Vladimirskogo yuridicheskogo instituta. 2014. № 2(31). S. 61-64. 


\section{Психология и психотехника 3(78) • 2015}

8. Sidorov D.V. Islamofobiya sovremennoi Rossii // Nauchno-analiticheskii zhurnal Obozrevatel'-Observer. 2014. № 5(292). S. 34-41.

9. Pogontseva D.V. Etno-lukizm: vzglyad na problemu // Natsional'naya bezopasnost' / nota bene. 2013. № 6. C. 144-150. (DOI: 10.7256/2073-8560.2013.6.9490).

10. Hopkins C.T. Social reproduction in France: Religious dress laws and laïcité // Women’s Studies International Forum, Vol. 48, January-February 2015, p. 154-164.

11. Tarasenko O.V. Khidzhab v islamskoi religii // Vestnik Moskovskogo gosudarstvennogo lingvisticheskogo universiteta. 2010. № 581. S. 217-226.

12. Dosanova M.G. Gorodskie zhenshchiny v khidzhabe. Novyi fenomen v Kazakhstane? // Vestnik RUDN. Seriya «Sotsiologiya». 2010. № 3. S. 5-11.

13. Ruby T.F. Listening to the voices of hijab // Women's Studies International Forum, Vol. 29, Iss. 1, January-February 2006, p. 54-66.

14. McDermott-Levy R. Going alone: The lived experience of female Arab-Muslim nursing students living and studying in the United States // Nursing Outlook, Volume 59, Issue 5, September-October 2011, Pages 266-277.e2.

15. Hassim N. Hijab and the Malay-Muslim Woman in Media // Procedia-Social and Behavioral Sciences, Vol. 155, 6 November 2014, p. 428-433.

16. Brown L., Brown J., Richards B. Media representations of Islam and international Muslim student well-being // International Journal of Educational Research, Vol. 69, 2015, p. 50-58.

17. Mahmud Y., Swami V. The influence of the hijab (Islamic head-cover) on perceptions of women's attractiveness and intelligence // Body Image, Vol. 7, Issue 1, January 2010, p. 90-93.

18. Wagner J.T. Do anti-immigrant sentiments track into Danish classrooms? Ethnicity, ethnicity salience, and bias in children's peer preferences / J.T. Wagner, L.B. Camparo, V. Tsenkova, J.C. Camparo // Intern. J. of Educ. Research. 2008. Vol. 47, is. 5. P. 312-322.

19. Arsel'gov A.U. Etnicheskie stereotipy v kul'ture: na primere kul'tur Severnogo Kavkaza: Dis. ... kand. filos. n. Rostov-na-Donu, 2011. $147 \mathrm{~s}$.

20. Ho C. Muslim women's new defenders: Women's rights, nationalism and Islamophobia in contemporary Australia // Women's Studies International Forum, Vol. 30, Iss. 4, July-August 2007, p. 290-298.

21. Pogontseva D.V., Nasedkina Yu.V. Otnoshenie molodezhi k raznym konfessiyam v zavisimosti ot ikh religioznoi identichnosti // Nauchno-metodicheskii elektronnyi zhurnal «Kontsept». 2014. T. 20. S. 4806-4810.

22. Pogontseva D.V., Nasedkina Yu.V. Otnoshenie molodezhi k predstavitelyam razlichnykh religioznykh konfessii // Education Sciences and Psychology. 2013. № 2(24). S. 49-53.

23. Labunskaya V.A. Interpretatsiya neverbal'nogo povedeniya v mezhlichnostnom obshchenii: Avtoref. dis. ... dokt. psikhol. n. M., 1989.

24. Labunskaya V.A., Mendzheritskaya Yu.A., Breus E.D. Psikhologiya zatrudnennogo obshcheniya: Teoriya. Metody. Diagnostika. Korrektsiya: Uchebn. pos. dlya stud. vysshikh uchebnykh zavedenii. M., 2001.

25. Labunskaya V.A., Bzezyan A.A. Metodologiya issledovaniya diskriminatsionnogo otnosheniya k predstavitelyam etnokul'turnykh grupp v razlichnykh situatsiyakh vzaimodeistviya // Teoreticheskie problemy etnicheskoi i kross-kul'turnoi psikhologii: Materialy chetvertoi mezhdunarodnoi nauchnoi konferentsii 30-31 maya 2014 g. / Otv. red. V.V. Gritsenko. Smolensk: Smolenskii gumanitarnyi universitet, 2014. T. 1. S. 50-55.

26. Pogontseva D.V. Predstavleniya sovremennoi molodezhi o vneshnei krasote zhenshchiny // Rossiiskii psikhologicheskii zhurnal. 2008. T. 5. № 4. S. 110-112.

27. Pogontseva D.V. K voprosu o diskriminatsiya po vneshnemu obliku // Severo-Kavkazskii psikhologicheskii vestnik. 2011. T. 9. № 2. S. 47-50.

28. Bzezyan A.A. Osobennosti etnicheskoi identichnosti kak prediktor prinyatiya diskriminatsionnogo otnosheniya $\mathrm{k}$ etnokul'turnym gruppam // Natsional'naya bezopasnost' / nota bene. 2014. № 3. S. 454-464. (D0I: 10.7256/20738560.2014.3.12083).

29. Pogontseva D.V. Vidy diskriminatsii po vneshnemu obliku // Psikhologiya i psikhotekhnika. 2013.№ 9. S. 858-861. (D0I: 10.7256/2070-8955.2013.9.9106).

30. Bzezyan A.A. Vliyanie gendera etnokul'turnogo tipa vneshnego oblika na stepen' pozitivnosti otsenki // Psikhologiya i psikhotekhnika. 2014. № 1. S. 83-90. (DOI: 10.7256/2070-8955.2014.1.9704). 